\title{
The Impact of Diet, Nutrition and Nutraceuticals on Oral and Periodontal Health
}

\author{
Gaetano Isola $\mathbb{D}$ \\ Department of General Surgery and Surgical-Medical Specialties, School of Dentistry, University of Catania, \\ Via S. Sofia 78, 95124 Catania, Italy; gaetano.isola@unict.it; Tel.: +39-095-3782453
}

Received: 21 August 2020; Accepted: 28 August 2020; Published: 6 September 2020

\begin{abstract}
Oral and periodontal diseases can determine severe functional, phonatory and aesthetic impairments and are the main cause of adult tooth loss. They are caused by some specific bacteria that provoke an intense local inflammatory response and affect-with particular gravity-susceptible subjects, because of reasons related to genetics and lifestyles (e.g., smoking and home oral hygiene habits). They are more frequent in the disadvantaged segments of society and, in particular, in subjects who have difficulty accessing preventive services and dental care. Some systemic diseases, such as uncontrolled diabetes, can increase their risk of development and progression. Recently, in addition to the obvious considerations of severe alterations and impairments for oral health and well-being, it has been noted that periodontitis can cause changes in the whole organism. Numerous clinical and experimental studies have highlighted the presence of a strong association between periodontitis and some systemic diseases, in particular, cardiovascular diseases, diabetes, lung diseases and complications of pregnancy. The purpose of this editorial is to provide a current and thoughtful perspective on the relationship of diet and natural agents on oral, periodontal diseases, and chewing disorder preventions which may reflect good systemic conditions and related quality of life or to analyze indirect effects through the contribution of diet and nutrition to systemic health in order to obtain a modern diagnostic-therapeutic approach.
\end{abstract}

Keywords: periodontitis; oral diseases; diet; nutrients; nutraceutics; therapy; host response

\section{Editorial}

Periodontitis is a multifactorial disease in which both environmental and genetic factors play a precise and controversial role in determining its onset [1]. Oral bacterial flora certainly plays an important role in the progression of this pathology. Further risk factors, widely studied, are smoking and diabetes [2-4]. However, a series of genetic factors of the host can condition the individual susceptibility to the onset of the disease, determine its different clinical manifestations and the rate of progression [5,6].

Unlike Mendelian genetic diseases, which are rare and caused by a single or few mutations, multifactorial diseases, such as periodontitis, are frequent and related to numerous environmental and genetic factors. Genetic factors are not real mutations, but genetic polymorphisms, also called susceptibility factors. Each of these is not necessary or sufficient to determine the disease, however, they are able to modify the risk of its onset $[7,8]$.

These polymorphisms are variations in the genetic code that can have different effects, for example, changing the levels of gene expression, causing slight functional changes of the coded molecules, making individuals more susceptible to the onset of a certain disease or to the appearance of clinical pictures more serious than the disease itself [9].

In recent years, investigations into susceptibility factors for the development of periodontal diseases have mainly focused on the study of genes that encode factors involved in modulating the immune 
response, cell surface receptors, chemokines, enzymes and proteins related to antigen recognition. Cytokines, such as IL-1A, IL-1B, IL-10 and IL-6, are key factors that mediate the inflammatory process in periodontal disease. They play a role in the activation, proliferation and differentiation of B cells, the main cells implicated in severe manifestations of periodontitis [10-13].

These genetic variations can, therefore, favour the progression of the disease, causing the classic trend, characterized by repeated cycles of tissue inflammation, followed by spontaneous remissions (defined as "pousses" trend) [14,15].

In periodontal disease, pathogenic bacteria accumulated in the subgingival sulcus are the environmental factors that influence the inflammatory response of the periodontal tissues [16,17]. However, a central role of diet, natural agents and nutraceutics are also considered indirectly responsible for the health of periodontal tissues and against alveolar bone resorption [18-22].

In this regard, Liu et al. [23] found that seven bacterial taxa, including Streptococcus sp., Ruminococcaceae sp., Haemophilus sp., Veillonella spp., Actinomyces odontolyticus, and Gemella haemolysans, were significantly altered after oolong tea consumption, and presented robust strong connections with other oral microbiota. These results suggest that sustained oolong tea consumption would modulate salivary microbiota and generate potential oral pathogen preventative benefits.

Since alveolar bone resorption is a key factor in periodontal disease, the vitamin D receptor (VDR) has been considered as a susceptibility factor in disease progression. Data in the literature support the existence of an association between common polymorphisms affecting candidate genes and periodontal disease [22,24,25].

Interestingly, most genetic studies of periodontitis have employed small cohorts. The limited statistical power of studies conducted with a low number of samples leads to an imprecise assessment of the level of genetic risk and the danger of obtaining false-positive and false-negative results.

Periodontitis develops severely in genetically predisposed individuals [26,27]. Genetic susceptibility is believed to be due to changes in the subject's genes that lead to (i) a lower efficiency of the immune system in controlling the growth of pathogenic bacteria; and/or (ii) an imperfect regulation of the inflammatory response [28-32] which leads to an increase in the destructive side effects of inflammation [33-36]. As a matter of fact, Jekabsone et al. [37] explored antibacterial, antinflammatory and cytoprotective capacity of Pelargonium sidoides DC root extract (PSRE) and proanthocyanidin fraction from PSRE (PACN) under conditions characteristic for periodontal disease. They found that PSRE and especially PACN possess strong antibacterial, anti-inflammatory and gingival tissue protecting properties under periodontitis-mimicking conditions and are suggestable candidates for the treatment of periodontal disease.

Great importance is also attached to lifestyles [38]; first of all, smoking and home oral hygiene habits, orthodontic treatment [39-42] and malocclusions [43-48], as they explain at an epidemiological level a large portion of the cases of periodontitis and dental malocclusions [49-51] observed and are modifiable and therefore important for prevention and treatment.

The general state of health of the subject is another element that can increase the risk of developing periodontitis. For example, people with poorly controlled diabetes have three times higher risk than non-diabetics of developing periodontitis [52,53].

Bodgdan et al. [54] conducted a systematic review of clinical trials that measured plasmatic/salivary levels of ascorbic acid in PD-diabetes mellitus (DM) association. They found that decreased levels of vitamin $C$ were observed in PD patients with DM but data about the efficacy of vitamin C administration are inconclusive. Given the important bidirectional relationship between PD and DM, there is a strong need for more research to assess the positive effects of ascorbic acid supplementation in individuals suffering from both diseases and also its proper regimen for these patients.

Moreover, in this aspect, Nastri et al. [55], in their scoping review, summarized the role of dietary supplements in optimizing osseointegration after implant insertion surgery. The authors concluded highlighting the limited role of nutraceuticals in promoting the osseointegration of dental implants. 
However, in some cases, such as for vitamin D deficiency, there is a clear link among their deficit, reduced osseointegration, and early implant failure, thus requiring an adequate supplementation.

Knowing the patient's genetic profile or their predisposition to the disease could be very useful in diagnosing periodontal disease and in defining a personalized therapeutic plan. In addition, it could give prognostic indications of the outcome of the disease.

Data derived from epidemiological observations are therefore important to establish the existence of a relevant and stable association but are insufficient to demonstrate the causal link and therefore the general health benefits deriving from the treatment and prevention of periodontitis. Causality can only be demonstrated unequivocally in randomized controlled trials that include eliminating or reducing (through prevention or therapy) the exposure of subjects to the harmful effects of periodontitis: pathogenic bacteria and gingival inflammation. These studies must conform to the highest quality standards and test the therapy capable of reducing the exposure in a clinically relevant way for each systemic pathology for which a significant association has emerged.

Funding: This research received no external funding.

Conflicts of Interest: The author declares no conflict of interest.

\section{References}

1. Aarabi, G.; Heydecke, G.; Seedorf, U. Roles of Oral Infections in the Pathomechanism of Atherosclerosis. Int. J. Mol. Sci. 2018, 19. [CrossRef]

2. Decker, A.; Askar, H.; Tattan, M.; Taichman, R.; Wang, H.L. The assessment of stress, depression, and inflammation as a collective risk factor for periodontal diseases: A systematic review. Clin. Oral Investig. 2020, 24, 1-12. [CrossRef] [PubMed]

3. Almeida, M.L.; Duarte, P.M.; Figueira, E.A.; Lemos, J.C.; Nobre, C.M.G.; Miranda, T.S.; de Vasconcelos Gurgel, B.C. Effects of a full-mouth disinfection protocol on the treatment of type-2 diabetic and non-diabetic subjects with mild-to-moderate periodontitis: One-year clinical outcomes. Clin. Oral Investig. 2020, 24, 333-341. [CrossRef] [PubMed]

4. Han, S.J.; Yi, Y.J.; Bae, K.H. The association between periodontitis and dyslipidemia according to smoking and harmful alcohol use in a representative sample of Korean adults. Clin. Oral Investig. 2020, 24, 937-944. [CrossRef]

5. Tonetti, M.S.; Greenwell, H.; Kornman, K.S. Staging and grading of periodontitis: Framework and proposal of a new classification and case definition. J. Periodontol. 2018, 89 (Suppl. S1), S159-S172. [CrossRef] [PubMed]

6. Marra, P.M.; Nucci, L.; Femiano, L.; Grassia, V.; Nastri, L.; Perillo, L. Orthodontic management of a mandibular double-tooth incisor: A case report. Open Dent. J. 2020, 14, 219-255. [CrossRef]

7. Tasdemir, I.; Erbak Yilmaz, H.; Narin, F.; Saglam, M. Assessment of saliva and gingival crevicular fluid soluble urokinase plasminogen activator receptor (suPAR), galectin-1, and TNF-alpha levels in periodontal health and disease. J. Periodontal. Res. 2020, 55, 622-630. [CrossRef]

8. Duarte, P.M.; de Lorenzo Abreu, L.; Vilela, A.; Feres, M.; Giro, G.; Miranda, T.S. Protein and mRNA detection of classic cytokines in corresponding samples of serum, gingival tissue and gingival crevicular fluid from subjects with periodontitis. J. Periodontal. Res. 2019, 54, 174-179. [CrossRef]

9. Nisha, K.J.; Janam, P.; Harshakumar, K. Identification of a novel salivary biomarker miR-143-3p for periodontal diagnosis: A proof of concept study. J. Periodontol. 2019, 90, 1149-1159. [CrossRef]

10. Isola, G.; Polizzi, A.; Santonocito, S.; Alibrandi, A.; Ferlito, S. Expression of Salivary and Serum Malondialdehyde and Lipid Profile of Patients with Periodontitis and Coronary Heart Disease. Int. J. Mol. Sci. 2019, 20. [CrossRef]

11. Isola, G.; Alibrandi, A.; Rapisarda, E.; Matarese, G.; Williams, R.C.; Leonardi, R. Association of vitamin D in patients with periodontitis: A cross-sectional study. J. Periodontal. Res. 2020, 55, 602-612. [CrossRef] [PubMed]

12. Ghotloo, S.; Motedayyen, H.; Amani, D.; Saffari, M.; Sattari, M. Assessment of microRNA-146a in generalized aggressive periodontitis and its association with disease severity. J. Periodontal. Res. 2019, 54, 27-32. [CrossRef] [PubMed] 
13. Marchetti, E.; Tecco, S.; Caterini, E.; Casalena, F.; Quinzi, V.; Mattei, A.; Marzo, G. Alcohol-free essential oils containing mouthrinse efficacy on three-day supragingival plaque regrowth: A randomized crossover clinical trial. Trials 2017, 18, 154. [CrossRef] [PubMed]

14. Arweiler, N.B.; Marx, V.K.; Laugisch, O.; Sculean, A.; Auschill, T.M. Clinical evaluation of a newly developed chairside test to determine periodontal pathogens. J. Periodontol. 2020, 91, 387-395. [CrossRef] [PubMed]

15. Bagavad Gita, J.; George, A.V.; Pavithra, N.; Chandrasekaran, S.C.; Latchumanadhas, K.; Gnanamani, A. Dysregulation of miR-146a by periodontal pathogens: A risk for acute coronary syndrome. J. Periodontol. 2019, 90, 756-765. [CrossRef]

16. Isola, G.; Alibrandi, A.; Curro, M.; Matarese, M.; Ricca, S.; Matarese, G.; Ientile, R.; Kocher, T. Evaluation of salivary and serum ADMA levels in patients with periodontal and cardiovascular disease as subclinical marker of cardiovascular risk. J. Periodontol. 2020, 91, 1076-1084. [CrossRef]

17. Mummolo, S.; Nota, A.; Albani, F.; Marchetti, E.; Gatto, R.; Marzo, G.; Quinzi, V.; Tecco, S. Salivary levels of Streptococcus mutans and Lactobacilli and other salivary indices in patients wearing clear aligners versus fixed orthodontic appliances: An observational study. PLOS ONE 2020, 15, e0228798. [CrossRef]

18. Vieira, A.R. Genetics of Periodontitis without Bias. J. Periodontal. Res. 2019, 54, 453-454. [CrossRef]

19. Li, G.; Robles, S.; Lu, Z.; Li, Y.; Krayer, J.W.; Leite, R.S.; Huang, Y. Upregulation of free fatty acid receptors in periodontal tissues of patients with metabolic syndrome and periodontitis. J. Periodontal. Res. 2019, 54, 356-363. [CrossRef]

20. Li, W.; Wang, X.; Tian, Y.; Xu, L.; Zhang, L.; Shi, D.; Feng, X.; Lu, R.; Meng, H. A novel multi-locus genetic risk score identifies patients with higher risk of generalized aggressive periodontitis. J. Periodontol. 2019, 91, 925-932. [CrossRef]

21. Isola, G. Current Evidence of Natural Agents in Oral and Periodontal Health. Nutrients 2020, 12. [CrossRef] [PubMed]

22. Isola, G.; Polizzi, A.; Iorio-Siciliano, V.; Alibrandi, A.; Ramaglia, L.; Leonardi, R. Effectiveness of a nutraceutical agent in the non-surgical periodontal therapy: A randomized, controlled clinical trial. Clin. Oral Investig. 2020. [CrossRef]

23. Liu, Z.; Guo, H.; Zhang, W.; Ni, L. Salivary Microbiota Shifts under Sustained Consumption of Oolong Tea in Healthy Adults. Nutrients 2020, 12. [CrossRef] [PubMed]

24. Yan, K.; Lin, Q.; Tang, K.; Liu, S.; Du, Y.; Yu, X.; Li, S. Substance P participates in periodontitis by upregulating HIF-1alpha and RANKL/OPG ratio. BMC Oral Health 2020, 20, 27. [CrossRef] [PubMed]

25. Lee, J.H.; Park, Y.S.; Kim, Y.T.; Kim, D.H.; Jeong, S.N. Assessment of early discomfort and wound healing outcomes after periodontal surgery with and without enamel matrix derivative: An observational retrospective case-control study. Clin. Oral Investig. 2020, 24, 229-237. [CrossRef] [PubMed]

26. Cosgarea, R.; Tristiu, R.; Dumitru, R.B.; Arweiler, N.B.; Rednic, S.; Sirbu, C.I.; Lascu, L.; Sculean, A.; Eick, S. Effects of non-surgical periodontal therapy on periodontal laboratory and clinical data as well as on disease activity in patients with rheumatoid arthritis. Clin. Oral Investig. 2019, 23, 141-151. [CrossRef] [PubMed]

27. Wang, X.; Li, W.; Song, W.; Xu, L.; Zhang, L.; Feng, X.; Lu, R.; Meng, H. Association of CYP1A1 rs1048943 variant with aggressive periodontitis and its interaction with hyperlipidemia on the periodontal status. J. Periodontal. Res. 2019, 54, 546-554. [CrossRef] [PubMed]

28. Leonardi, R.; Loreto, C.; Talic, N.; Caltabiano, R.; Musumeci, G. Immunolocalization of lubricin in the rat periodontal ligament during experimental tooth movement. Acta. Histochem. 2012, 114, 700-704. [CrossRef]

29. Leonardi, R.; Almeida, L.E.; Trevilatto, P.C.; Loreto, C. Occurrence and regional distribution of TRAIL and DR5 on temporomandibular joint discs: Comparison of disc derangement with and without reduction. Oral Surg. Oral Med. Oral Pathol. Oral Radiol. Endod. 2010, 109, 244-251. [CrossRef]

30. Musumeci, G.; Trovato, F.M.; Loreto, C.; Leonardi, R.; Szychlinska, M.A.; Castorina, S.; Mobasheri, A. Lubricin expression in human osteoarthritic knee meniscus and synovial fluid: A morphological, immunohistochemical and biochemical study. Acta Histochem 2014, 116, 965-972. [CrossRef]

31. Mercuri, E.; Cassetta, M.; Cavallini, C.; Vicari, D.; Leonardi, R.; Barbato, E. Dental anomalies and clinical features in patients with maxillary canine impaction. Angle Orthod. 2013, 83, 22-28. [CrossRef] [PubMed]

32. Leonardi, R.; Farella, M.; Cobourne, M.T. An association between sella turcica bridging and dental transposition. Eur. J. Orthod. 2011, 33, 461-465. [CrossRef] [PubMed] 
33. de, J.H.M.C.; Villafuerte, K.R.V.; Luchiari, H.R.; de, O.C.J.; Sales, M.; Palioto, D.B.; Messora, M.R.; Souza, S.L.S.; Taba, M., Jr.; Ramos, E.S.; et al. Effect of smoking on the DNA methylation pattern of the SOCS1 promoter in epithelial cells from the saliva of patients with chronic periodontitis. J. Periodontol. 2019, 90, 1279-1286. [CrossRef]

34. Taiete, T.; Casati, M.Z.; Martins, L.; Andia, D.C.; Mofatto, L.S.; Coletta, R.D.; Monteiro, M.F.; Araujo, C.F.; Santamaria, M.P.; Correa, M.G.; et al. Novel rare frameshift variation in aggressive periodontitis: Exomic and familial-screening analysis. J. Periodontol. 2020, 91, 263-273. [CrossRef] [PubMed]

35. Mijailovic, I.; Nikolic, N.; Djinic, A.; Carkic, J.; Milinkovic, I.; Peric, M.; Jankovic, S.; Milasin, J.; Aleksic, Z. The down-regulation of Notch 1 signaling contributes to the severity of bone loss in aggressive periodontitis. J. Periodontol. 2020, 91, 554-561. [CrossRef] [PubMed]

36. Briguglio, F.; Zenobio, E.G.; Isola, G.; Briguglio, R.; Briguglio, E.; Farronato, D.; Shibli, J.A. Complications in surgical removal of impacted mandibular third molars in relation to flap design: Clinical and statistical evaluations. Quintessence Int. 2011, 42, 445-453.

37. Jekabsone, A.; Sile, I.; Cochis, A.; Makrecka-Kuka, M.; Laucaityte, G.; Makarova, E.; Rimondini, L.; Bernotiene, R.; Raudone, L.; Vedlugaite, E.; et al. Investigation of Antibacterial and Antiinflammatory Activities of Proanthocyanidins from Pelargonium sidoides DC Root Extract. Nutrients 2019, 11. [CrossRef]

38. Lo Giudice, A.; Ortensi, L.; Farronato, M.; Lucchese, A.; Lo Castro, E.; Isola, G. The step further smile virtual planning: Milled versus prototyped mock-ups for the evaluation of the designed smile characteristics. BMC Oral Health 2020, 20, 165. [CrossRef]

39. Daniele, V.; Macera, L.; Taglieri, G.; Di Giambattista, A.; Spagnoli, G.; Massaria, A.; Messori, M.; Quagliarini, E.; Chiappini, G.; Campanella, V.; et al. Thermoplastic Disks Used for Commercial Orthodontic Aligners: Complete Physicochemical and Mechanical Characterization. Materials 2020, 13. [CrossRef]

40. Saccomanno, S.; Quinzi, V.; Sarhan, S.; Lagana, D.; Marzo, G. Perspectives of tele-orthodontics in the COVID-19 emergency and as a future tool in daily practice. Eur. J. Paediatr. Dent. 2020, 21, 157-162. [CrossRef]

41. Rosa, M.; Quinzi, V.; Marzo, G. Paediatric Orthodontics Part 1: Anterior open bite in the mixed dentition. Eur. J. Paediatr. Dent. 2019, 20, 80-82. [CrossRef] [PubMed]

42. Lo Giudice, A.; Quinzi, V.; Ronsivalle, V.; Farronato, M.; Nicotra, C.; Indelicato, F.; Isola, G. Evaluation of Imaging Software Accuracy for 3-Dimensional Analysis of the Mandibular Condyle. A Comparative Study Using a Surface-to-Surface Matching Technique. Int. J. Environ. Res. Public Health 2020, 17. [CrossRef]

43. Lo Giudice, A.; Leonardi, R.; Ronsivalle, V.; Allegrini, S.; Lagravère, M.; Marzo, G.; Isola, G. Evaluation of pulp cavity/chamber changes after tooth-borne and bone-borne rapid maxillary expansion. A CBCT study using surface-based superimposition and deviation analysis. Clin. Oral Investig. 2020. [CrossRef] [PubMed]

44. Lo Giudice, A.; Caccianiga, G.; Crimi, S.; Cavallini, C.; Leonardi, R. Frequency and type of ponticulus posticus in a longitudinal sample of nonorthodontically treated patients: Relationship with gender, age, skeletal maturity, and skeletal malocclusion. Oral Surg. Oral Med. Oral Pathol. Oral Radiol. 2018, 126, 291-297. [CrossRef] [PubMed]

45. Lo Giudice, A.; Nucera, R.; Perillo, L.; Paiusco, A.; Caccianiga, G. Is Low-Level Laser Therapy an Effective Method to Alleviate Pain Induced by Active Orthodontic Alignment Archwire? A Randomized Clinical Trial. J. Evid. Based Dent. Pract. 2019, 19, 71-78. [CrossRef]

46. Lo Giudice, A.; Rustico, L.; Caprioglio, A.; Migliorati, M.; Nucera, R. Evaluation of condylar cortical bone thickness in patient groups with different vertical facial dimensions using cone-beam computed tomography. Odontology 2020, 108, 669-675. [CrossRef]

47. Lo Giudice, A.; Spinuzza, P.; Rustico, L.; Messina, G.; Nucera, R. Short-term treatment effects produced by rapid maxillary expansion evaluated with computer tomography: A systematic review with meta-analysis. The Korean J. Orthod. 2020, 37. [CrossRef]

48. Perillo, L.; Padricelli, G.; Isola, G.; Femiano, F.; Chiodini, P.; Matarese, G. Class II malocclusion division 1: A new classification method by cephalometric analysis. Eur. J. Paediatr. Dent. 2012, 13, 192-196.

49. Marra, P.; Nucci, L.; Abdolreza, J.; Perillo, L.; Itro, A.; Grassia, V. Odontoma in a young and anxious patient associated with unerupted permanent mandibular cuspid: A case report. J. Int. Oral Health 2020, 12, 182-186. [CrossRef] 
50. Cozzani, M.; Nucci, L.; Lupini, D.; Dolatshahizand, H.; Fazeli, D.; Barzkar, E.; Naeini, E.; Jamilian, A. The ideal insertion angle after immediate loading in Jeil, Storm, and Thunder miniscrews: A 3D-FEM study. Int. Orthod. 2020, 18, 503-508. [CrossRef]

51. Cozzani, M.; Sadri, D.; Nucci, L.; Jamilian, P.; Pirhadirad, A.P.; Jamilian, A. The effect of Alexander, Gianelly, Roth, and MBT bracket systems on anterior retraction: A 3-dimensional finite element study. Clin. Oral Investig. 2020, 24, 1351-1357. [CrossRef] [PubMed]

52. Shinjo, T.; Ishikado, A.; Hasturk, H.; Pober, D.M.; Paniagua, S.M.; Shah, H.; Wu, I.H.; Tinsley, L.J.; Matsumoto, M.; Keenan, H.A.; et al. Characterization of periodontitis in people with type 1 diabetes of 50 years or longer duration. J. Periodontol. 2019, 90, 565-575. [CrossRef] [PubMed]

53. Morelli, T.; Moss, K.L.; Preisser, J.S.; Beck, J.D.; Divaris, K.; Wu, D.; Offenbacher, S. Periodontal profile classes predict periodontal disease progression and tooth loss. J. Periodontol. 2018, 89, 148-156. [CrossRef]

54. Bogdan, M.; Meca, A.D.; Boldeanu, M.V.; Gheorghe, D.N.; Turcu-Stiolica, A.; Subtirelu, M.S.; Boldeanu, L.; Blaj, M.; Botnariu, G.E.; Vlad, C.E.; et al. Possible Involvement of Vitamin C in Periodontal Disease-Diabetes Mellitus Association. Nutrients 2020, 12. [CrossRef] [PubMed]

55. Nastri, L.; Moretti, A.; Migliaccio, S.; Paoletta, M.; Annunziata, M.; Liguori, S.; Toro, G.; Bianco, M.; Cecoro, G.; Guida, L.; et al. Do Dietary Supplements and Nutraceuticals Have Effects on Dental Implant Osseointegration? A Scoping Review. Nutrients 2020, 12. [CrossRef] [PubMed]

(C) 2020 by the author. Licensee MDPI, Basel, Switzerland. This article is an open access article distributed under the terms and conditions of the Creative Commons Attribution (CC BY) license (http://creativecommons.org/licenses/by/4.0/). 